\title{
Improvement of the embryonic stem cell test endpoint analysis by use of field potential detection
}

\author{
Naoteru Koseki, Jiro Deguchi, Toru Yamada, Hitoshi Funabashi and Takaki Seki \\ Safety Research Laboratories, Dainippon Sumitomo Pharma Co., Ltd., 33-94 Enoki-cho, Suita, Osaka 564-0053, \\ Japan
}

(Received March 29, 2010; Accepted May 24, 2010)

\begin{abstract}
The embryonic stem cell test (EST) is a validated in vitro method to assess the embryotoxic potential of compounds and is a promising tool for drug screening. EST requires microscopic observation of beating cardiomyocytes differentiated from embryonic stem cells as a toxicological endpoint. However, this process is time-consuming and lacks throughput performance. To improve the analysis, we introduced an electrophysiological method with a microelectrode array system for the evaluation of differentiated cardiomyocytes. Embryotoxic (valproic acid, verapamil, and 5-fluorouracil) and non-embryotoxic (penicillin G, d-camphor, and isoniazid) compounds were assessed with the system. Mouse embryonic stem cells were differentiated into cardiomyocytes and treated with each compound during the differentiation process. The embryotoxicity of each compound was then assessed by measuring the field potentials of differentiated cardiomyocytes using the microelectrode array system, as well as by microscopic evaluation. All the embryotoxic compounds dose-dependently inhibited the field potential formation and the myocardial beating of differentiated cells, while the non-embryotoxic compounds did not affect either endpoint. The detection capabilities of the two assay methods were similar. These results indicated that the field potential measurements can be used as an alternative endpoint of EST. Moreover, the field potential can be measured automatically, introducing a high throughput performance compared to the conventional microscopic observation. We therefore concluded that the endpoint analysis with the microelectrode array system improves the original EST and can be useful for the assessment of the embryotoxic potential of compounds.
\end{abstract}

Key words: Cardiomyocyte, Embryonic stem cell, Embryonic stem cell test (EST), Embryotoxicity, Field potential, Microelectrode array system

\section{INTRODUCTION}

Various adverse effects of drugs have been reported since the 1950's, and efforts to avoid these side effects remain a great issue in drug development. Especially, embryotoxicity, the effect of inducing abnormality in developmental processes, is considered as one of the most severe adverse reactions. For example, thalidomide, originally developed as a hypnotic agent, was found to be embryotoxic to humans after its launch and caused severe drug-induced birth defects such as malformations of the hands and feet. Due to such serious effects, embryotoxic compounds have been withdrawn from the market or stringently restricted to the limited clinical indication. Therefore, it is important to assess the embryotoxic potential of drug candidates.

In the early stage of drug development, in vitro methods are more suitable than the traditional in vivo experimental methods in terms of cost and the amount of samples necessary to evaluate the embryotoxic potential of test compounds. Some well-known methods to evaluate embryotoxic potential in vitro include those using micromass culture or whole embryo culture (Brown, 1987; Brown et al., 1995; Spielmann et al., 2004; Piersma et al., 2004). However, both methods require embryos from experimental animals for the assays. Moreover, it is difficult to sustain exposure to a test compound throughout the entire period of organogenesis in these assays, because the micromass or cultured whole embryo cannot be maintained over $48 \mathrm{hr}$ under the current technology.

Correspondence: Naoteru Koseki (E-mail: naoteru-koseki@ds-pharma.co.jp) 
Recently, examinations using embryonic stem cells (ES cells) have been reported as novel in vitro assay methods for the screening of embryotoxicity (Scholz et al., 1999; Pellizzer et al., 2005). The embryonic stem cell test (EST) has been validated by the European Centre for the Validation of Alternative Methods (ECVAM) to assess the embryotoxic potential of compounds and its results are reported to correlate well with those of in vivo methods (Genschow et al., 2004). In EST, the ES cells are exposed to a test compound throughout the entire differentiation stage and therefore the effects of the compound can be assessed throughout the period of organogenesis. Thus, it is thought that EST is suitable for in vitro early drug screening for embryotoxicity.

On the other hand, some serious problems have been noted for the original EST, especially in the area of sufficient throughput performance. The most serious problem of EST is mainly caused by its endpoint analysis. EST requires the microscopic observation of beating cardiomyocytes differentiated from ES cells as a toxicological endpoint. This microscopic observation is time-consuming and lacks throughput performance. To resolve the problem, several approaches to automate the endpoint assay were reported. These included the reporter gene assay (Bremer et al., 2001) and the biomarker analysis for differentiated cardiomyocytes (Seiler et al., 2004; Buesen et al., 2009). In the reporter gene assay, expression of the GFP gene driven by $\alpha$-actin promoter was assessed automatically using a flow cytometer or fluorescence microplate reader. In the assays with biomarkers, expression of $\alpha$-actin or myosin heavy chain (MHC) protein was stained with immunofluorescent antibody and automatically measured by the flow cytometry. However, neither method was suitable for high throughput screening, as the devices used for the analysis had limited throughput. Moreover, $\alpha$-actin and MHC were not specific biomarkers for cardiomyocytes and their application as differentiation biomarkers in EST seemed questionable. Another attempt for the automation was reported (Peters et al., 2008). In their method, differentiation process of ES cells was recorded in a video system and the beating of cardiomyocytes was automatically detected using image analysis. This method, however, required processing of large amounts of image data, which made it difficult to use the method in routine drug screening.

Recently, it was reported that the extracellular field potential of ES-cell-derived cardiomyocytes could be measured by a microelectrode array system (Banach et al., 2003; Satin et al., 2004; Kolossov et al., 2005; Reppel et al., 2005). Cardiomyocytes are cells that beat spontaneously, and this beating is accompanied by an oscillation of the field potential. Therefore, beating cardiomyocytes can be found automatically by measuring the field potential with a microelectrode system. Based on the above findings, we selected the field potential as a parameter for the differentiation of ES cells into cardiomyocytes and tried to establish an alternative endpoint for EST.

\section{MATERIALS AND METHODS}

\section{Cell culture}

BALB/c 3T3 cells (3T3 cells, clone A31, ATCC No. CCL-163) were obtained from American Type Culture Collection (Manassas, VA, USA) and maintained in high glucose Dulbecco's modified Eagle's medium (DMEM, Invitrogen, Carlsbad, CA, USA) supplemented with $10 \%$ fetal calf serum (FCS, Invitrogen), $50 \mathrm{U} / \mathrm{ml}$ penicillin (MP Biomedicals, Solon, OH, USA), and $50 \mu \mathrm{g} / \mathrm{ml}$ streptomycin (MP Biomedicals). Mouse embryonic stem cells (ES cells, line D3, ATCC No. CCL-1934) were obtained from American Type Culture Collection and maintained in DMEM (Millipore, Billerica, MA, USA) supplemented with $15 \%$ fetal calf serum (Thermo Trace, Noble Park, VIC, Australia), $50 \mathrm{U} / \mathrm{ml}$ penicillin (Millipore), $50 \mu \mathrm{g} /$ $\mathrm{ml}$ streptomycin (Millipore), $2 \mathrm{mM}$ glutamine (Millipore), $1 \%$ non-essential amino acids, $1 \%$ nucleosides, $1 \%$ $\beta$-mercaptoethanol, and 1,000 U/ml leukemia inhibitory factor (LIF, Millipore).

\section{Test compounds}

Valproic acid, verapamil, and 5-fluorouracil were selected as test compounds with known embryotoxic potential in vivo. Penicillin G, isoniazid, and d-camphor were selected as test compounds without embryotoxic potential in vivo. All chemicals were purchased from Sigma-Aldrich Corp. (Saint Louis, MO, USA). Each test compound was dissolved in dimethylsulfoxide (DMSO, Sigma-Aldrich). The final concentration of DMSO in culture medium was $0.5 \%(\mathrm{v} / \mathrm{v})$. The concentrations of valproic acid, 5-fluorouracil, isoniazid, and d-camphor for the cytotoxicity assays were set from 500 to $0.015 \mu \mathrm{g} / \mathrm{ml}$, those of verapamil were set from 1,500 to $0.05 \mu \mathrm{g} / \mathrm{ml}$, and those of penicillin $\mathrm{G}$ were set from 1,000 to $0.03 \mu \mathrm{g} / \mathrm{ml}$, with a dilution factor of 3 for all ranges of test compound solutions. The concentrations of each test compound for the differentiation assay were set based on the results of the cytotoxicity assay.

\section{Cytotoxicity assay using 3 T 3 cells and ES cells}

On the first day, 3T3 or ES cells (3,000 cells/well) were individually seeded into each well of a 96-well microtitre plate. On the next day, test compounds in culture medi- 
Improvement of the embryonic stem cell test endpoint analysis

um without LIF were applied to the wells. Each test concentration was tested in quadruplicate wells. After 2 days from the initial exposure to the test compounds, viability of the cells was determined by measuring the intracellular ATP concentration (Cell Titer-Glo Luminescent Cell Viability Assay, Promega, Madison, WI, USA). Cytotoxicity $\left(\mathrm{IC}_{50} 3 \mathrm{~T} 3\right.$ for $3 \mathrm{~T} 3$ cells and $\mathrm{IC}_{50} \mathrm{D} 3$ for $\mathrm{ES}$ cells) was calculated from a concentration-response curve and expressed as the concentration inhibiting the cell growth by $50 \%$ compared to the respective control level.

\section{Differentiation assay in the microscopic observation}

ES cells were cultured with the hanging drop method (750 cells in $20 \mu \mathrm{l}$ of droplets placed on the lid of a culture dish) (Day 0 ) and maintained for 3 days in the absence of LIF to allow differentiation. Several concentrations of each test compound were added to individual cell droplets. On Day 3, embryoid bodies (EBs) formed in the hanging drop culture were collected into low adherent culture dishes and maintained in the medium containing the test compound for 2 days. On Day 5, each EB was seeded separately into one well of a 24-well gelatin-coated culture plate so the cells could attach onto the bottom of the culture plate and differentiate into beating cardiomyocytes. One 24-well plate was used for each concentration of a test compound, and one plate for the vehicle control. On Day 10, differentiation from ES cells into cardiomyocytes was assessed by judging the presence of beating under microscopic observation. The incidence of wells (i.e. EBs) of each plate in which beating cardiomyocytes was developed was determined and compared to that of the vehicle control plate. The inhibition of differentiation $\left(\mathrm{ID}_{50}\right)$ was calculated from a concentrationresponse curve and expressed as the concentration of the test compound inhibiting the development into beating cardiomyocytes by $50 \%$.

\section{Differentiation assay in the field potential measurement using the microelectrode array system}

Hanging drop culture and EB collection of ES cells were conducted as described above (Section 2.4). On Day 5, each EB was seeded separately into one well of a gelatin-coated chamber with a microelectrode array (MED Probe, MED-P545A, Alpha MED Scientific, Osaka, Japan). During the time from Day 5 to Day 10, EBs attached to the bottom of the chamber and differentiated into beating cardiomyocytes. A set of twelve chambers with microelectrode arrays was used for each concentration of a test compound, and a set for the vehicle con- trol. On Day 10, differentiation of ES cells into cardiomyocytes was assessed by measuring the field potential with the microelectrode array system (MED64 system, Alpha MED Scientific). The incidence of chambers with the field potential formation was determined and compared to that of the vehicle control. $\mathrm{ID}_{50}$ was calculated from a concentration-response curve and expressed as the concentration of the test compound inhibiting the development into beating cardiomyocytes by $50 \%$.

\section{Classification of the embryotoxicity}

Classification of the embryotoxic potential of each test compound was calculated based on the 3 values, $\mathrm{IC}_{50} 3 \mathrm{~T} 3$, $\mathrm{IC}_{50} \mathrm{D} 3$, and $\mathrm{ID}_{50}(\mu \mathrm{g} / \mathrm{ml})$, using with the prediction model proposed by ECVAM (Table1).

\section{Statistical analysis}

The concordance between determination by microscopic observation and by microelectrode array system was assessed by Fisher's exact test. A two-sided P value of $<0.0001$ was considered extremely significant.

\section{RESULTS}

\section{Cytotoxicity assay using 3 T 3 cells and ES cells}

The cytotoxicity assay was conducted to determine the concentrations of the test compounds in the differentiation assay. Results are shown in Fig. 1. In the groups treated with valproic acid, verapamil, and 5-fluorouracil, the cell viability of $3 \mathrm{~T} 3$ cells and ES cells decreased dosedependently. In the groups treated with penicillin G, isoniazid, and d-camphor, the cell viability of 3T3 cells and ES cells did not decrease up to the highest dose.

The calculated $\mathrm{IC}_{50}$ values in $3 \mathrm{~T} 3$ and ES cells are shown in Table 2. In the groups treated with verapamil and 5-fluorouracil, the $\mathrm{IC}_{50}$ values of ES cells were smaller than those of 3T3 cells. In the groups treated with other compounds, the $\mathrm{IC}_{50}$ values of ES cells were almost the same with those of $3 \mathrm{~T} 3$ cells.

\section{Concordance between determination by microscopic observation and by microelectrode array system}

To confirm that the field potential reflects the actual beating of cardiomyocytes, we checked whether the assay chambers in which the beating cardiomyocytes were observed by microscopic observation correctly corresponded to the assay chambers in which the field potentials were detected by the microelectrode array. A few EBs cultured in the chambers with the microelectrode arrays were observed under the microscope on Day 10 after the 
Table 1. Prediction model of the embryotoxic potential

(A) Linear discriminant of functions I, II, and III

\begin{tabular}{cc}
\hline Function & Linear discriminant \\
\hline $\mathrm{I}$ & $5.92 \times \log \left(\mathrm{IC}_{50} 3 \mathrm{~T} 3\right)+3.50 \times \log \left(\mathrm{IC}_{50} \mathrm{D} 3\right)-5.31 \times\left(\mathrm{IC}_{50} 3 \mathrm{~T}_{3}-\mathrm{ID}_{50}\right) / \mathrm{IC}_{50} 3 \mathrm{~T} 3-15.7$ \\
$\mathrm{II}$ & $3.65 \times \log \left(\mathrm{IC}_{50} 3 \mathrm{~T} 3\right)+2.39 \times \log \left(\mathrm{IC}_{50} \mathrm{D} 3\right)-2.03 \times\left(\mathrm{IC}_{50} 3 \mathrm{~T}_{3}-\mathrm{ID}_{50}\right) / \mathrm{IC}_{50} 3 \mathrm{~T} 3-6.85$ \\
$\mathrm{III}$ & $-0.125 \times \log \left(\mathrm{IC}_{50} 3 \mathrm{~T} 3\right)-1.92 \times \log \left(\mathrm{IC}_{50} \mathrm{D} 3\right)+1.50 \times\left(\mathrm{IC}_{50} 3 \mathrm{~T}_{3}-\mathrm{ID}_{50}\right) / \mathrm{IC}_{50} 3 \mathrm{~T} 3-2.67$ \\
\hline
\end{tabular}

(B) Classification criteria

\begin{tabular}{ccc}
\hline Classification & Embryotoxic Potential & Criteria \\
\hline 1 & non & Function I $>$ II and I $>$ III \\
2 & weak & Function II $>$ I and II $>$ III \\
3 & strong & Function III $>$ I and III $>$ II \\
\hline
\end{tabular}

The prediction model of the embryotoxic potential for a test compound proposed by ECVAM was applied. The values of endpoint analysis $\left(\mathrm{IC}_{50} 3 \mathrm{~T} 3, \mathrm{IC}_{50} \mathrm{D} 3\right.$, and $\left.\mathrm{ID}_{50}\right)$ are used to calculate each function in $(\mathrm{A})$. Classification of the embryotoxic potential of the test compound (not, weakly, or strongly embryotoxic) is determined by comparing each function value as shown in (B).

Table 2. $\mathrm{IC}_{50}$ in $3 \mathrm{~T} 3$ and ES cells

\begin{tabular}{lcc}
\hline Test compound & $\begin{array}{l}\mathrm{IC}_{50} 3 \mathrm{~T} 3 \\
(\mu \mathrm{g} / \mathrm{ml})\end{array}$ & $\begin{array}{l}\mathrm{IC}_{50} \mathrm{D} 3 \\
(\mu \mathrm{g} / \mathrm{ml})\end{array}$ \\
\hline Valproic acid & $>500$ & $>500$ \\
Verapamil & 61 & 17 \\
5-Fluorouracil & 14 & 0.2 \\
Penicillin G & $>1000$ & $>1000$ \\
Isoniazid & $>500$ & $>500$ \\
d-Camphor & $>500$ & $>500$ \\
\hline
\end{tabular}

The values of $\mathrm{IC}_{50}$ were calculated from the concentrationresponse curve in $3 \mathrm{~T} 3$ and $\mathrm{ES}$ cells. $\mathrm{IC}_{50} 3 \mathrm{~T} 3$ indicates the values of $\mathrm{IC}_{50}$ in $3 \mathrm{~T} 3$ cells. $\mathrm{IC}_{50} \mathrm{D} 3$ indicates the values of $\mathrm{IC}_{50}$ in $\mathrm{ES}$ cells.

initiation of the assay, and the field potentials were detected at the identical EBs. A typical example is shown in Fig. 2. The concordance of results between microscopic observation and microelectrode array detection is shown in Table 3. The determinations by microscopic observation and by the microelectrode array system assay were compared (Table 3 (A)). Seventy-five of the 85 chambers assessed by the microelectrode array system were correctly judged as having or not having cardiomyocytes. Ten of the 85 chambers assessed by the microelectrode array system were falsely judged as not having cardiomyocytes. No chambers assessed by the microelectrode array system were incorrectly judged as having cardio- myocytes. Additionally, the correlativity of the microelectrode array system assay against microscopic observation was assessed (Table 3 (B)). The predictivity for presence or absence of cardiomyocytes, precision for presence or absence of cardiomyocytes, and accuracy were $100 \%$, $57 \%, 86 \%, 100 \%$, and $88 \%$, respectively. On the other hand, the concordance between determination by microscopic observation and by microelectrode array system was assessed by Fisher's exact test. There was a significant association between these methods (two-sided $\mathrm{P}$ value $<0.0001)$. These data indicated that the field potential method reflected the actual beating of cardiomyocytes with about $90 \%$ of accuracy in comparison to microscopic observation.

\section{Differentiation assay by microscopic observation and by field potential measurement}

Three embryotoxic and 3 non-embryotoxic compounds were assessed for their embryotoxic potentials to ES cells by the microscopic observation and by the field potential measurement, and the results were compared. Results are shown in Figs. 3 and 4. In both methods, valproic acid, verapamil, and 5-fluorouracil inhibited the differentiation of ES cells in a dose-dependent manner. On the other hand, penicillin G, isoniazid, and d-camphor did not significantly decrease the differentiation ratio in either method. The differentiation ratios for each compound assessed by the field potential detection were almost the same as those by the conventional microscopic observation.

$\mathrm{ID}_{50}$ values were calculated based on the above results 
Improvement of the embryonic stem cell test endpoint analysis
(A) Valproic acid
(B) Verapamil
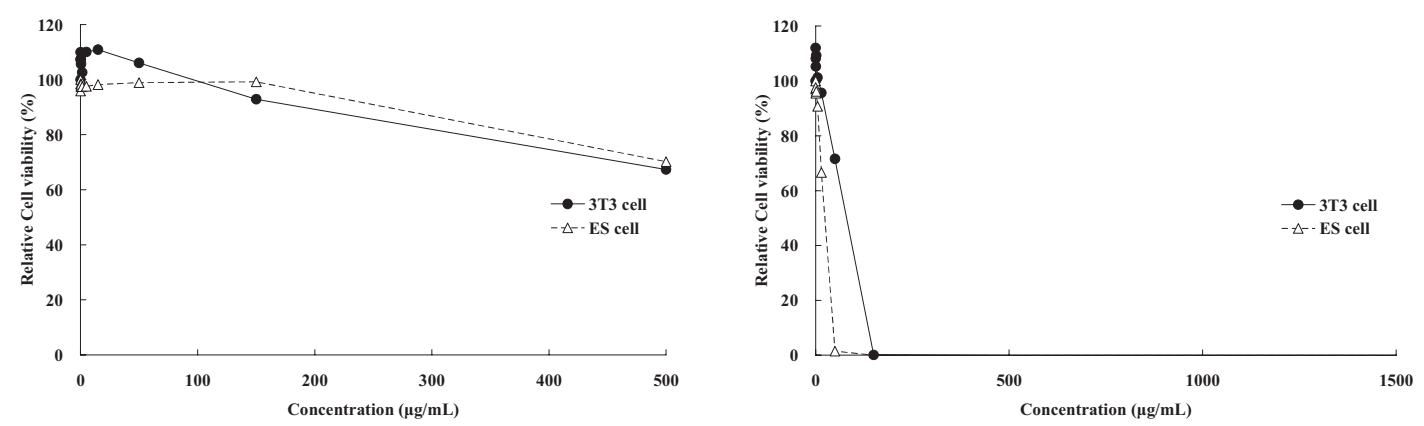

(C) 5-Fluorouracil

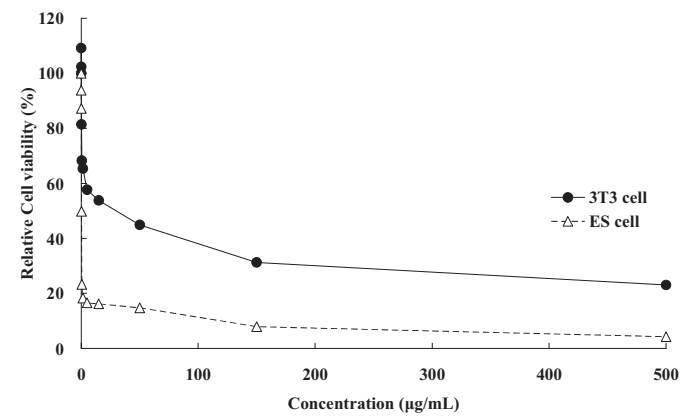

(E) Isoniazid

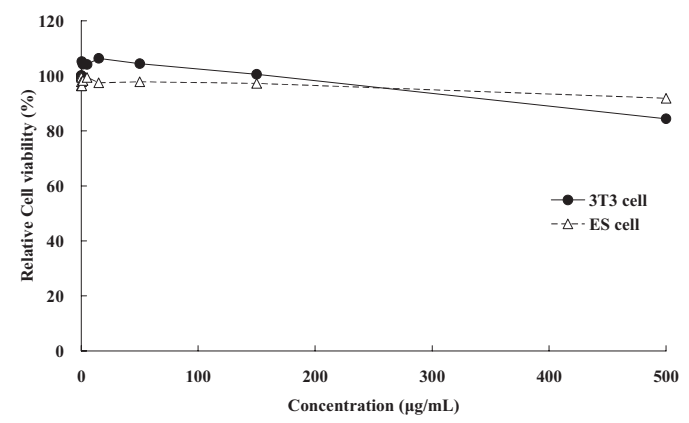

(D) Penicillin G

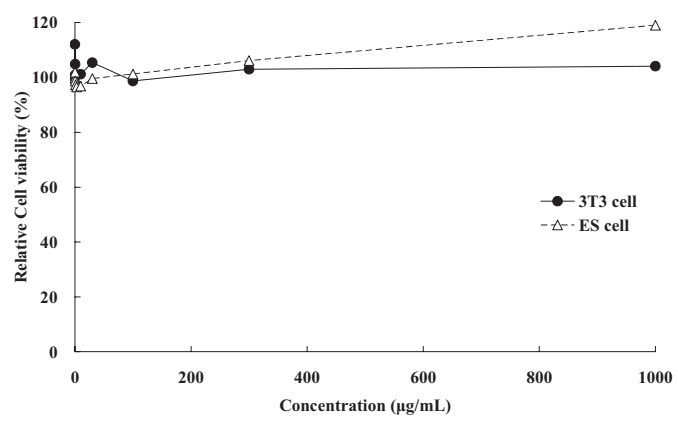

(F) d-Camphor

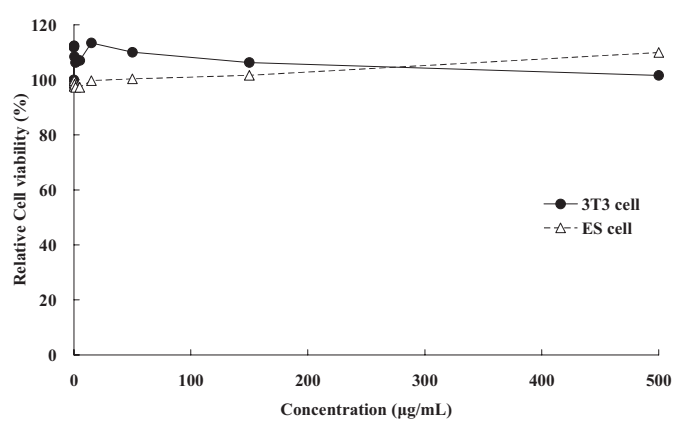

Fig. 1. Cytotoxicity in $3 \mathrm{~T} 3$ and ES cells treated with the test compounds. The cytotoxicity of each compound is represented as the cell viability relative to the respective control value. Symbols are indicated as follows: $(\bullet), 3$ T3 cells; $(\Delta)$, ES cells.

(Table 4). The $\mathrm{ID}_{50}$ values assessed by the field potential detection were almost the same as those by microscopic observation.

\section{Classification of the embryotoxic potential}

Results of the cytotoxicity and differentiation assays by microscopic observation and field potential measurement were combined, and each test compound was classified 


\section{N. Koseki et al.}

Table 3. Confirmation of the concordance between determinations by microscopic observation and by the microelectrode array system assay

(A) Comparison between determinations by microscopic observation and by the microelectrode array system assay

\begin{tabular}{cccc}
\hline \multirow{2}{*}{ Method } & & \multicolumn{2}{c}{ Microelectrode array system } \\
\cline { 3 - 4 } & & Present & Absent \\
\hline \multirow{2}{*}{ Microscopic observation } & Present & $62^{\mathrm{a}}$ & $10^{\mathrm{b}}$ \\
& Absent & $0^{\mathrm{c}}$ & $13^{\mathrm{d}}$ \\
\hline
\end{tabular}

(B) Correlativity of the microelectrode array system assay against microscopic observation

\begin{tabular}{lcc}
\hline Evaluation index & Calculating formula & Value of probability $(\%)$ \\
\hline Predictivity for presence of cardiomyocytes & $\mathrm{a} /(\mathrm{a}+\mathrm{c}) \times 100$ & 100 \\
Predictivity for absence of cardiomyocytes & $\mathrm{d} /(\mathrm{b}+\mathrm{d}) \times 100$ & 57 \\
Precision for presence of cardiomyocytes & $\mathrm{a} /(\mathrm{a}+\mathrm{b}) \times 100$ & 86 \\
Precision for absence of cardiomyocytes & $\mathrm{d} /(\mathrm{c}+\mathrm{d}) \times 100$ & 100 \\
Accuracy & $(\mathrm{a}+\mathrm{d}) /(\mathrm{a}+\mathrm{b}+\mathrm{c}+\mathrm{d}) \times 100$ & 88 \\
\hline
\end{tabular}

A total of 85 assay chambers were tested for the concordance between the results by microscopic observation and by the microelectrode system. "Present" and "Absent" numbers in (A) indicate the number of assay chambers in which cardiomyocytes were judged as present or absent by each method. Variables a, b, c, and d in calculating formula in (B) indicate the number of assay chambers in (A).

Table 4. $\mathrm{ID}_{50}$ assessed by microscopic observation and the microelectrode array system assay

\begin{tabular}{lcc}
\hline \multirow{2}{*}{ Test compound } & \multicolumn{2}{c}{$\mathrm{ID}_{50}(\mu \mathrm{g} / \mathrm{ml})$} \\
\cline { 2 - 3 } & $\begin{array}{c}\text { Microscopic } \\
\text { observation }\end{array}$ & $\begin{array}{c}\text { Microelectrode array } \\
\text { system assay }\end{array}$ \\
\hline Valproic acid & 24 & 29 \\
Verapamil & 0.50 & 0.19 \\
5-Fluorouracil & 0.004 & 0.010 \\
Penicillin G & $>1000$ & 774 \\
Isoniazid & $>300$ & $>300$ \\
d-Camphor & 234 & 245 \\
\hline
\end{tabular}

The values of $\mathrm{ID}_{50}$ assessed by microscopic observation and the microelectrode array system assay were calculated from the concentration-response curve in the differentiation assay using ES cells.

according to its calculated embryotoxic potential (Table 5). The classified categories in the present study were then compared with those shown in the ECVAM validation study as well as the classifications from the conventional in vivo studies. The classified categories predicted by the microscopic observation and by the field poten- tial measurement were identical, and these categories also matched with the embryotoxic data in the ECVAM validation study. d-Camphor was predicted as class 2 in the present study while it was reported as class 1 in an in vivo study. This was the only compound for which the classification in the present study did not match with that in the conventional in vivo study (Table 5).

\section{DISCUSSION}

Embryotoxicity is one of the most severe drug-induced adverse effects, and embryotoxic compounds have been withdrawn from the market or their clinical indications have been restricted. Therefore, it is very important to select embryotoxicity-free candidates in drug development. In the early drug development stage, an in vitro assay system is preferably used for screening, and to date there are several in vitro methods to detect the embryotoxicity of compounds. These include methods using micromass culture or whole embryo culture. Recently, EST has been developed as a convenient and promising in vitro method for the screening of embryotoxic compounds. EST does not require embryos for the assay, and therefore it has a great advantage over micromass and whole embryo cultures. The conventional EST, however, has some tech- 
Improvement of the embryonic stem cell test endpoint analysis

(A) Image of an EB on the microelectrode array assay chamber.

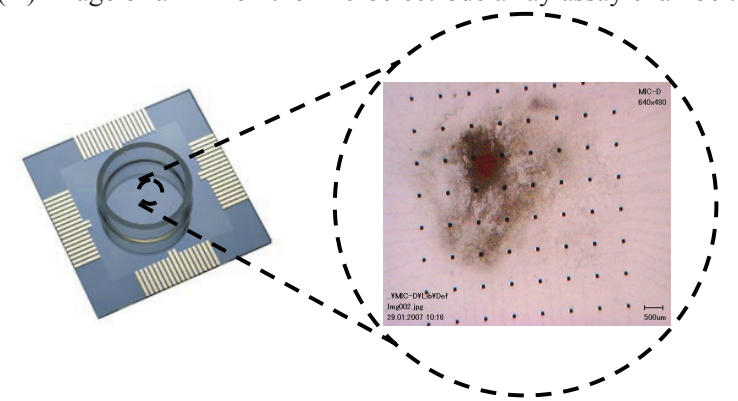

(B) An example of extracellular field potential measurements.

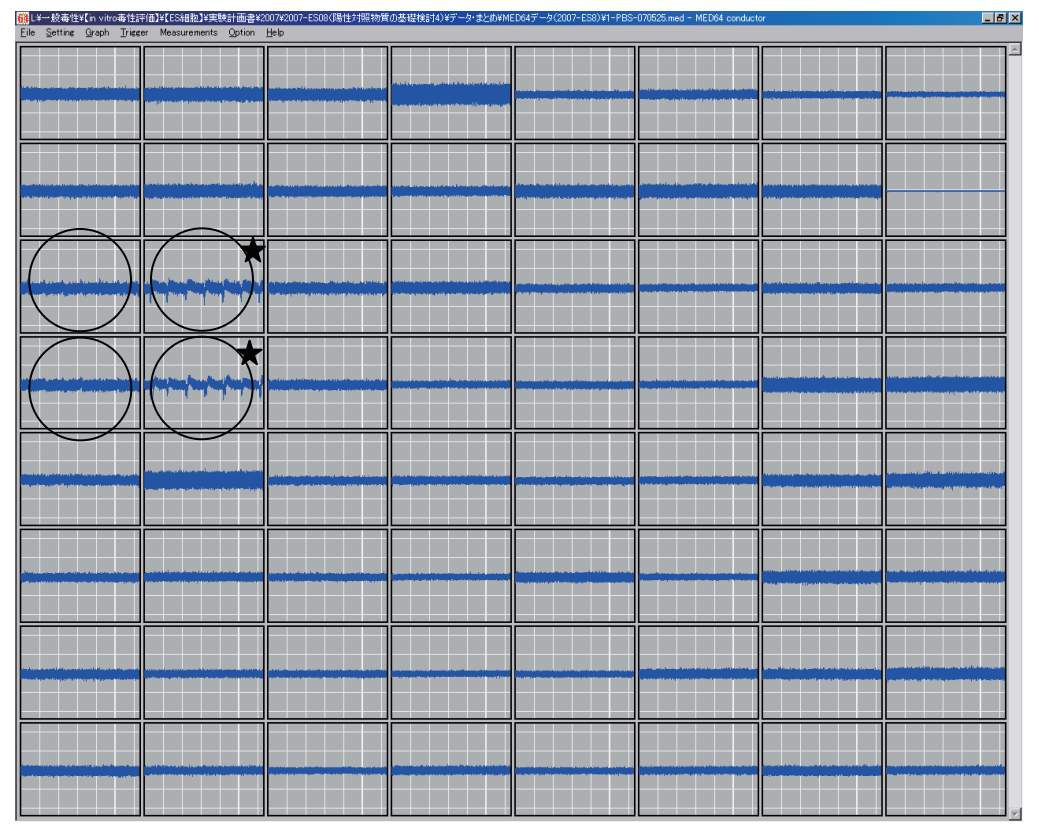

Fig. 2. Confirmation of the beating cardiomyocytes and the extracellular field potential. Fig. (A) shows an EB cultured on the microelectrode array assay chamber on Day 10 after the initiation of the assay. An EB is attached to the bottom of the chamber with electrodes. Fig. (B) shows an example of the extracellular field potential. Square areas on the measurement screen correspond to electrodes in the chamber. The circles indicate areas in which field potential generation was detected. The star symbols indicate the areas in which the beating of differentiated cardiomyocytes was observed.

nical problems for routine screening. The most important problem lies in the manual analysis of its differentiation assay. This process requires laborious and time-consuming microscopic observations that hinder its throughput performance. Recently, it was reported that the spontaneous extracellular field potential of ES-cell-derived cardiomyocytes could be measured by microelectrode array systems. Spontaneous extracellular field potential is considered as a specific endpoint to identify cardiomyocytes, because cardiomyocytes are the only cells that generate a spontaneous extracellular field potential. Moreover, the field potential can be assessed automatically with a micro- electrode system. However, application of field potential measurement has so far been limited to the establishment of an in vitro cardiotoxicity screening method and no attempt to apply the field potential measurement to EST as an endpoint of cardiomyocyte differentiation has been reported. Based on the above findings, we tried to establish an endpoint analysis by measuring the field potential in differentiating cardiomyocytes as an alternative method to the conventional microscopic judgment.

Initially, we tested whether the field potential reflected the actual beating of cardiomyocytes. The assay chambers in which the beating cardiomyocytes were observed 
N. Koseki et al.

(A) Valproic acid

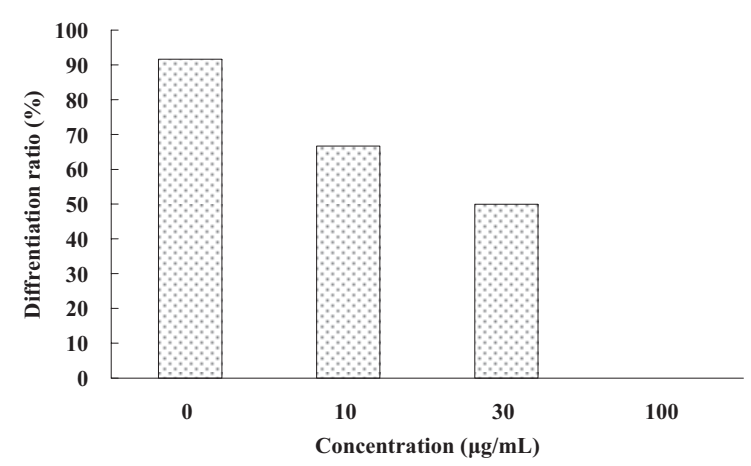

Microscopic observation

(B) Verapamil

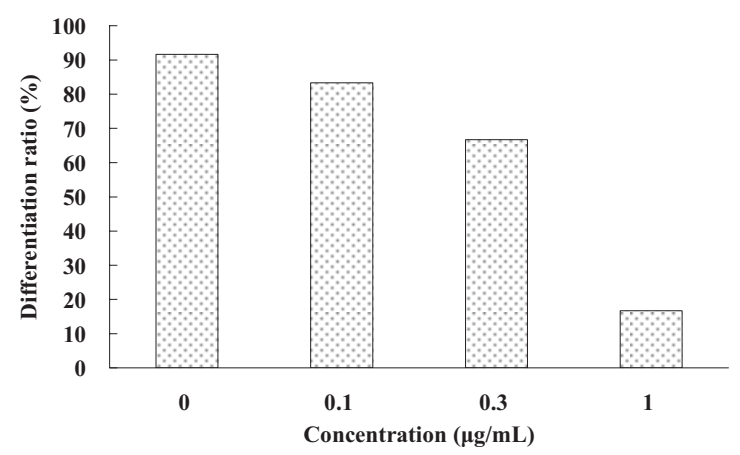

Microscopic observation

(C) 5-Fluorouracil

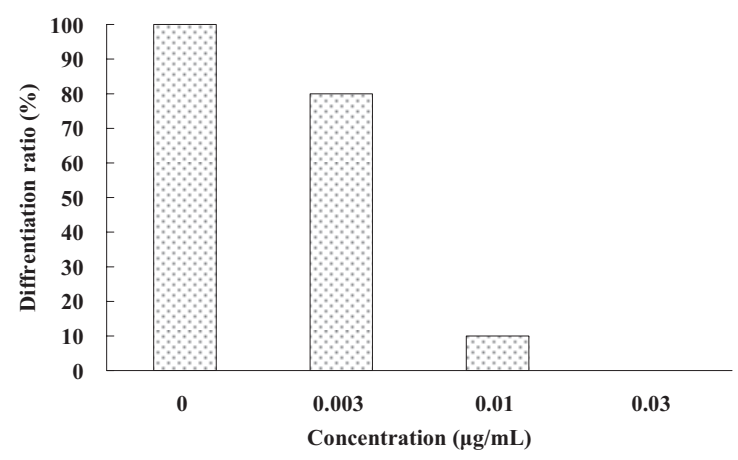

Microscopic observation

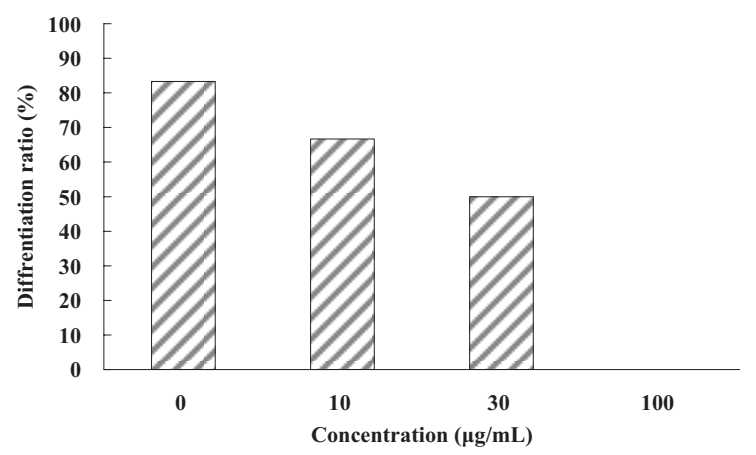

Microelectrode array system assay

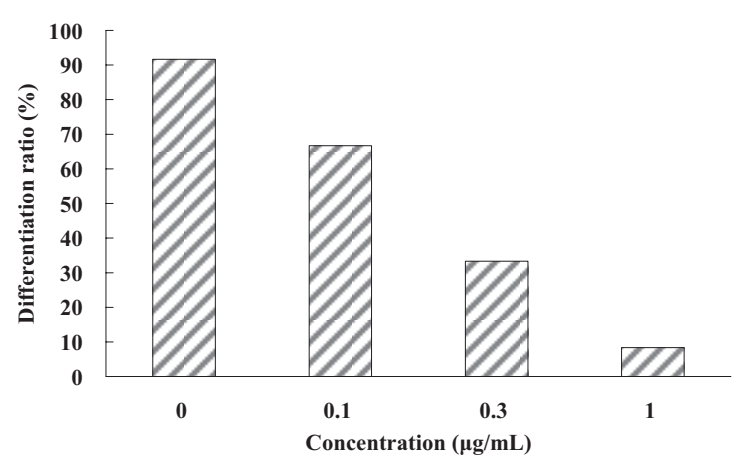

Microelectrode array system assay

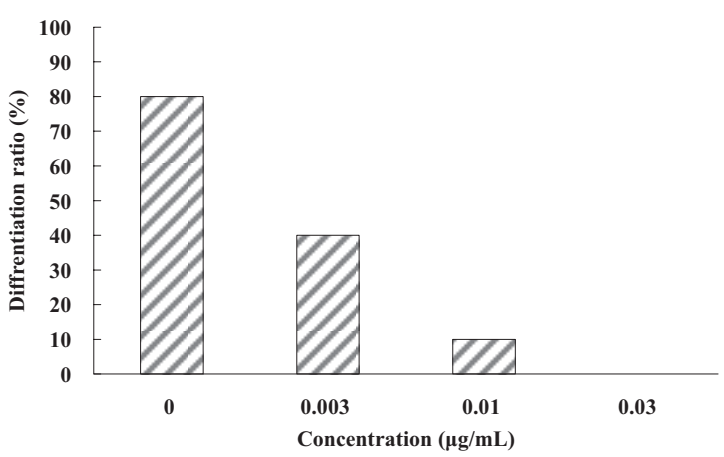

Microelectrode array system assay

Fig. 3. Differentiation ratio of ES cells into cardiomyocytes after treatment with the test compounds positive for embryotoxicity. The left graph for each compound indicates the differentiation ratio assessed by microscopic observation and the right graph indicates the differentiation ratio assessed by the microelectrode array system assay. 
Improvement of the embryonic stem cell test endpoint analysis

\section{(A) Penicillin G}

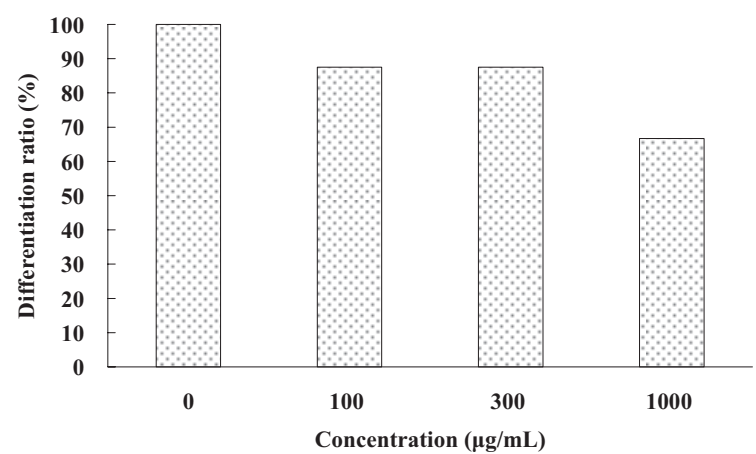

Microscopic observation

(B) Isoniazid

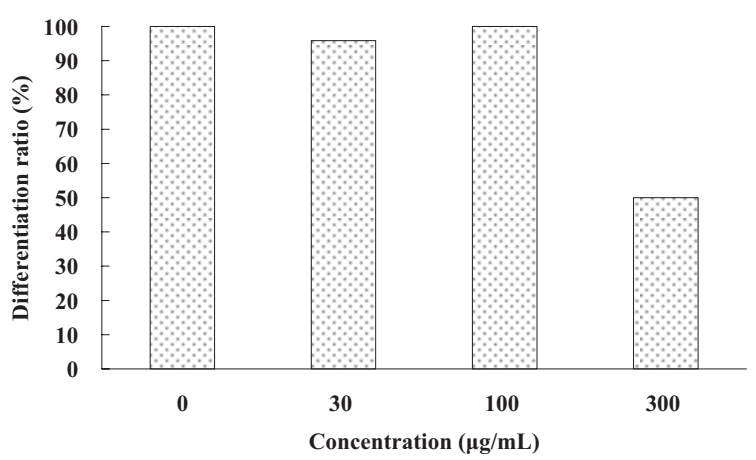

Microscopic observation

\section{(C) d-Camphor}

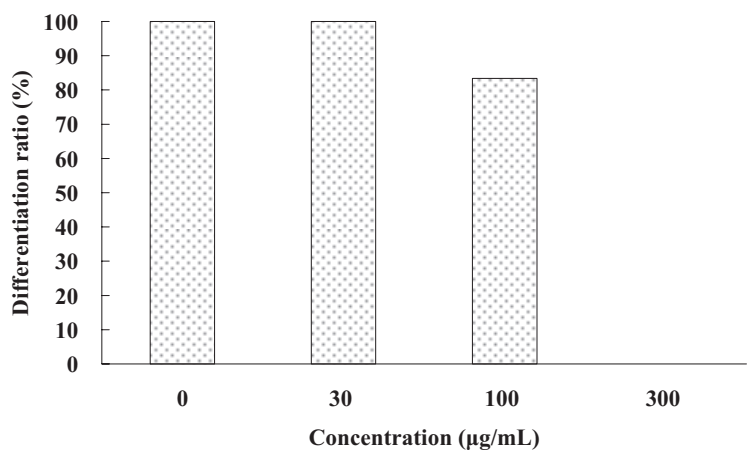

Microscopic observation

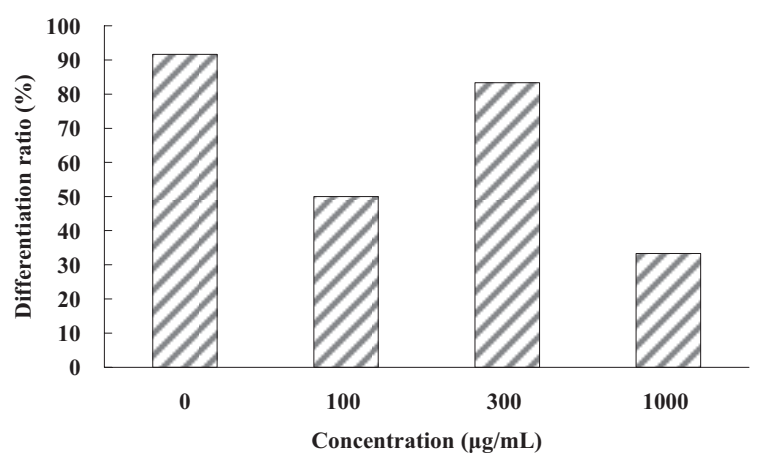

Microelectrode array system assay

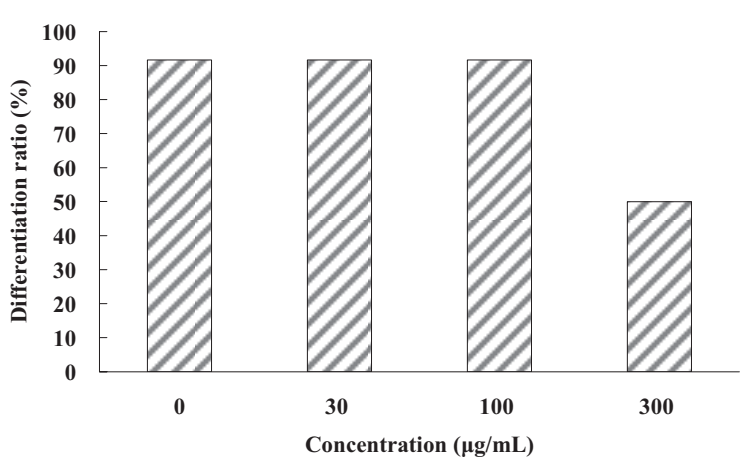

Microelectrode array system assay

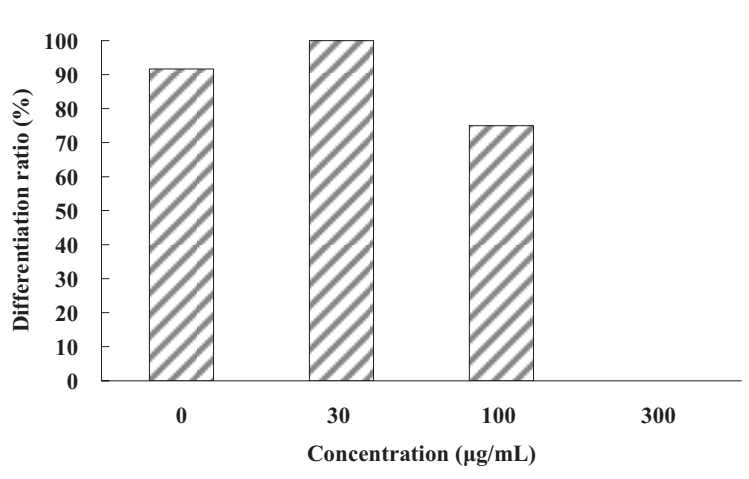

Microelectrode array system assay

Fig. 4. Differentiation ratio of ES cells into cardiomyocytes after treatment with the test compounds negative for embryotoxicity. The left graph for each compound indicates the differentiation ratio assessed by microscopic observation and the right graph indicates the differentiation ratio assessed by the microelectrode array system assay. 
N. Koseki et al.

Table 5. Classification of the embryotoxic potential assessed by in vitro and in vivo methods

\begin{tabular}{|c|c|c|c|c|}
\hline \multirow[b]{2}{*}{ Test compound } & \multicolumn{3}{|c|}{ Prediction embryotoxic classification in vitro } & \multirow[b]{2}{*}{$\begin{array}{c}\text { Embryotoxic } \\
\text { classification in vivo } \\
\text { (Reference) }\end{array}$} \\
\hline & $\begin{array}{l}\text { Microscopic } \\
\text { observation }\end{array}$ & $\begin{array}{l}\text { Microelectrode array } \\
\text { system assay }\end{array}$ & $\begin{array}{l}\text { ECVAM validation } \\
\text { (Reference: Genschow } \\
\text { et al., 2004) }\end{array}$ & \\
\hline Valproic acid & Class 2 & Class 2 & Class 2 & $\begin{array}{c}\text { Class } 2 \\
\text { (Sucheston } \text { et al., 1979) }\end{array}$ \\
\hline Verapamil & Class 2 & Class 2 & - & $\begin{array}{c}\text { Class } 2 \\
\text { (Jaffee and Jaffee, 1989) }\end{array}$ \\
\hline 5-Fluorouracil & Class 3 & Class 3 & Class 3 & $\begin{array}{c}\text { Class } 3 \\
\text { (Miyazaki et al., 1974) }\end{array}$ \\
\hline Penicillin G & Class 1 & Class 1 & Class 1 & $\begin{array}{c}\text { Class } 1 \\
\text { (Pfizer, 2005) }\end{array}$ \\
\hline Isoniazid & Class 1 & Class 1 & Class 1 & $\begin{array}{c}\text { Class } 1 \\
\text { (Sanofi-Aventis, 2007) }\end{array}$ \\
\hline d-Camphor & Class 2 & Class 2 & Class 1- 2 & $\begin{array}{c}\text { Class } 1 \\
\text { (Leuschner, 1997) }\end{array}$ \\
\hline
\end{tabular}

Classification of the embryotoxicity potential of each test compound was obtained from in vitro or in vivo assay. Class 1 , Class 2 , and Class 3 indicate no, weak, and strong embryotoxic potential, respectively.

by microscopic observation were compared to the assay chambers in which the field potentials were detected by the microelectrode array. About $90 \%$ of the assessed chambers were correctly judged about the presence or the absence of cardiomyocytes by the microelectrode array system, in comparison to the microscopic observations. These results suggested that the field potential measurements can be used as an alternative parameter to the conventional microscopic examination. In the next step, we assayed 3 embryotoxic and 3 non-embryotoxic compounds by EST using the two endpoints, the conventional microscopic observation and the field potential detection, and compared the results. All the embryotoxic test compounds dose-dependently inhibited the field potential formation as well as the visually detectable myocardial beating of differentiated cells. The differentiation rates assessed by the two endpoints were almost identical at each dose of each test compound. The non-embryotoxic test compounds did not affect either endpoint. The differentiation rates assessed using the two endpoints were also almost the same at each dose of each test compound. The $\mathrm{ID}_{50}$ values and the classified categories of each compound assessed using both endpoints matched well with each other. The classifications of the test compounds determined in the present study were parallel to those in the ECVAM validation study and those in conventional in vivo studies. These results suggested that the field potential measurement had similar sensitivity to the conven- tional microscopic method.

The field potential can be measured automatically by using a commercially available microelectrode array system. This automatic analysis accelerated throughput and assay performance by 2 -fold.

The reporter gene assay, flow cytometry assay, and image recording assay were reported as attempts to automate the endpoint assay of EST. However, the specificity of the indicator molecules ( $\alpha$-actin and MHC) is questionable in the reporter gene and flow cytometry assays, as those molecules are expressed not only in cardiomyocytes but also in other types of cells. The image recording assay requires a large amount of data processing of live video recording, restricting rapid analysis. In contrast, unlike the reporter gene and flow cytometry assays, the microelectrode array system can directly detect the differentiation into cardiomyocytes by measuring the spontaneous extracellular field potential. This system requires only a small amount of data processing as compared to the image recording assay. Therefore, it is considered that the field potential measurement assay is adapted for embryotoxicity screening from the viewpoints of the differentiation specificity to cardiomyocytes and the efficiency of data processing.

In the present study, we demonstrated that incorporation of field potential measurement made EST a more convenient assay method, with increased throughput performance. If we can develop a multi-channel and multi-well microelec- 
Improvement of the embryonic stem cell test endpoint analysis

trode device for the field potential detection, the throughput of EST will be dramatically improved. That advancement would help us screen the embryotoxicity of compounds at a very early stage of drug development and promote the development of a embryotoxicity-free compounds.

\section{ACKNOWLEDGMENTS}

The authors thank Mr. Y. Iwamura, Pharmacology Research Laboratories of Dainippon Sumitomo Pharma Co., Ltd., and Mr. H. Jiko, Director of Alpha MED Scientific Inc., for supporting the usage of the MED64 system. The authors also thank Ms. S. Ohi, Safety Research Laboratories of Dainippon Sumitomo Pharma Co., Ltd. for supporting the data acquisition in this study.

\section{REFERENCES}

Banach, K., Halbach, M.D., Hu, P., Hescheler, J. and Egert, U. (2003): Development of electrical activity in cardiac myocyte aggregates derived from mouse embryonic stem cells. Am. J. Physiol. Heart Cric. Physiol., 284, 2114-2123.

Bremer, S., Worth, A.P., Paparella, M., Bigot, K., Kolossov, E., Fleischmann, B.K., Hescheler, J. and Balls, M. (2001): Establishment of an in vitro reporter gene assay for developmental cardiac toxicity. Toxicol. in Vitro, 15, 215-223.

Brown, N.A. (1987): Teratogenicity testing in vitro: status of validation studies. Arch. Toxicol. Suppl., 11, 105-114.

Brown, N.A., Spielmann, H., Bechter, R., Flint, O.P., Freeman, S.J., Jelinek, R.J., Koch, E., Nau, H., Newall, D.R., Palmer, A.K., Renault, J.Y., Repetto, M.F., Vogel, R. and Wiger, R. (1995): Screening chemicals for reproductive toxicity: the current alternatives. Aletern. Lab. Anim., 23, 868-882.

Buesen, R., Genschow, E., Slawik, B., Visan, A., Spielmann, H., Luch, A. and Seiler, A. (2009): Embryonic stem cell test remastered: comparison between the validated EST and the new molecular FACS-EST for assessing developmental toxicity in vitro. Toxicol. Sci., 108, 389-400.

Genschow, E., Spielmann, H., Scholz, G., Pohl, I., Seiler, A., Clemann, N., Bremer, S. and Becker, K. (2004): Validation of the embryonic stem cell test in the international ECVAM validation study on three in vitro embryotoxicity tests. Aletern. Lab. Anim., 32, 209-244.

Jaffee, O.C. and Jaffee, A.L. (1989): The effects of verapamil on the developing cardiovascular system. Anat. Rec., 223, 56A.

Kolossov, E., Lu, Z., Drobinskaya, I., Gassanov, N., Duan, Y., Sauer, H., Manzke, O., Bloch, W., Bohlen, H., Hescheler, J. and Fleischmann, B.K. (2005): Identification and characterization of embryonic stem cell-derived pacemaker and atrial cardiomyocytes. FASEB J., 19, 577-579.

Leuschner, J. (1997): Reproductive toxicity studies of D-camphor in rats and rabbits. Arzneimittelforschung, 47, 124-128.

Miyazaki, H., Imamura, S., Koyama, K., Hara, T., Nishikawa, S., Shiramizu, K., Ohguro, Y. and Shimizu, M. (1974): Safety evaluation of oral 5-Fluorouracil (Acute, subacute, chronic toxicity and teratological studies). Kiso to Rinsyou, 8, 2603-2640.

Pellizzer, C., Bremer, S. and Hartung, T. (2005): Developmental toxicity testing from animal towards embryonic stem cells.
ALTEX, 22, 47-57.

Peters, A.K., Wouwer, G.V., Weyn, B., Verheyen, G.R., Vanparys, P. and Gompel, J.V. (2008): Automated analysis of contractility in the embryonic stem cell test, a novel approach to assess embryotoxicity. Toxicol. in Vitro, 22, 1948-1956.

Piersma, A.H., Genschow, E., Verhoef, A., Spanjersberg, M.Q., Brown, N.A., Brady, M., Burns, A., Clemann, N., Seiler, A. and Spielmann, H. (2004): Validation of the postimplantation rat whole-embryo culture test in the international ECVAM validation study on three in vitro embryotoxicity tests. Aletern. Lab. Anim., 32, 275-307.

Pfizer (2005): Buffered PFIZERPEN (penicillin G potassium) for Injection. U.S. Physician Prescribing Information.

Reppel, M., Pillekamp, F., Brockmeier, K., Matzkies, M., Bekcioglu, A., Lipke, T., Nguemo, F., Bonnemeier, H. and Hescheler, J. (2005): The electrocardiogram of human embryonic stem cellderived cardiomyocytes. J. Electrocardiol., 38, 166-170.

Sanofi-Aventis (2007): RIFAMATE (rifampin and isoniazid capsules USP). Prescribing Information.

Satin, J., Kehat, I., Caspi, O., Huber, I., Arbel, G., Itzhaki, I., Magyar, J., Schroder, E.A., Perlman, I. and Gepstein, L. (2004): Mechanism of spontaneous excitability in human embryonic stem cell derived cardiomyocytes. J. Physiol., 559, 479-496.

Scholz, G., Genschow, E., Pohl, I., Bremer, S., Paparella, M., Raabe, H., Southee, J. and Spielmann, H. (1999): Prevalidation of the embryonic stem cell test (EST) - a new in vitro embryotoxicity test. Toxicol. in Vitro, 13, 675-681.

Seiler, A., Visan, A., Buesen, R., Genschow, E. and Spielmann, H. (2004): Improvement of an in vitro stem cell assay for developmental toxicity: the use of molecular endpoints in the embryonic stem cell test. Reprod. Toxicol., 18, 231-240.

Spielmann, H., Genschow, E., Brown, N.A., Piersma, A.H., Verhoef, A., Spanjersberg, M.Q., Huuskonen, H., Paillard, F. and Seiler, A. (2004): Validation of the rat limb bud micromass test in the international ECVAM validation study on three in vitro embryotoxicity tests. Aletern. Lab. Anim., 32, 245-274.

Sucheston, M.E., Hayes, T.G., Paulson, R.B. and King, J.E. (1979): Fetal Malformations in Valproate Sodium Treated CD-I Mice. Teratology, 19, 49A. 